\title{
The Interrelation of Information Technology Governance and Enterprise Risk Management to The Organization's Performance: A Review of Empirical Literature
}

\author{
Kevin Bastian Sirait \\ Center for Risk Management and Sustainability, Jl. Batununggal Indah IV No. 97, Bandung, Indonesia
}

\begin{abstract}
Given that the role of information technology (IT) governance and enterprise risk management (ERM) within the organization are imperative due to the ever-increasing complexity in the corporate environment, this study aims to uncover the relationship between IT governance and ERM along with the impact of the two frameworks' interconnectedness on the organization's performance through empirical literature review. Furthermore, the findings obtained from the empirical review are also used to create a checklist that every organization can apply. The purpose of the created checklist is to help organizations examine the interconnectedness of their IT governance and ERM with respect to their needs and objectives. The findings from the empirical review show that both IT governance and ERM emphasize the importance of strategic and process alignment regarding its implementation, and it is positively significant to the organization's performance. Hence, the level of effectiveness of one's IT- and risk-oriented approaches are dictated by how well an organization appropriately aligns its IT governance and ERM structure, mechanism, and process with its objectives, needs, and business operations.
\end{abstract}

Keywords: Information technology, enterprise risk management, IT governance, empirical review

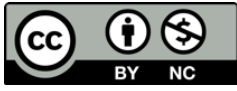

This is an open access article under the CC-BY-NC license.

\section{INTRODUCTION}

Considering the technological advances at a rapid pace in the recent decades and risks are interdependent by nature, the implementation of information technology (IT) governance and enterprise risk management (ERM) within the organization's practice is no longer a luxury but rather a necessity. Within this digital age, the world is more and more interconnected, and the use of technology has become ubiquitous in the enterprise landscape. Consequently, the exposure of digital and technological risks gradually becomes stronger, and it also increases the likelihood for cyber-related incidents to occur (see Bouveret, 2018; Cisco, 2020). In which those risks have the potential to harm the organizations' wellbeing either financially or otherwise. Consequently, every organization is facing a more significant risk exposure within a very volatile environment by default.

Due to this circumstance, both IT governance and ERM have become essential for any organization to cope with the uncertainties, risks, and challenges that reside within their corporate environment. At its core, the role of IT governance and ERM within the organization's business and operational activities are associated with one's capability to acquire competitive advantage and ensure their development and growth are sustainable within a highly dynamic environment (see Nolan and McFarlan, 2005; see Nocco and Stulz, 2006; Trautman and Altenbaumer-Price, 2011). Furthermore, the fundamental purpose of implementing and integrating IT governance and ERM within an organization's practice is to create, enhance, and protect its value. Therefore, the role of IT governance and ERM goes beyond simply tackling technical issues.

Although the relationship between IT governance and ERM have been explored and analyzed extensively (see, e.g., Wilkin and Chenhall, 2010; Rubino and Vitolla, 2014), it remains limited under the empirical standpoint. Especially on the research that uses a statistical approach in investigating the relationship between IT governance and ERM concerning the organization's performance. Some studies (e.g., Bowen, 
Cheung and Rohde, 2007; Turel and Bart, 2014) have shown that IT governance positively affects the organization's performance when its IT strategy and process are properly aligned with the organization's needs and objectives. Additionally, the applied IT governance must be supported with an adequate organizational structure, oversight procedures, resource allocation, and continuous improvement to ensure its IT is able to provide the expected level of support in aiding the organization to achieve its objectives. A similar pattern also occurs in other studies (e.g., Farrell and Gallagher, 2015; Alijoyo, Bonita and Sirait, 2021) concerning the influence of ERM on the organization's performance, which shows that the degree of ERM integration within the organization's activities determines its performance level. In this context, an organization with a mature ERM practice has reached the stage where a risk-oriented perspective is embedded at the strategic level, the idea of risk culture and process are clearly defined and understood in every layer of the management, and the risk-based decisions taken by the organization revolves around its needs and objectives. Following those findings, it has become more apparent that the purpose of IT governance and ERM is to aid organizations in achieving their objectives through strategic and process alignment. Consequently, the call for better understanding and insights concerning the relationship between two frameworks are increasingly become more pronounced and, at the same time, the need for an approach to check whether the implemented IT governance and ERM are aligned with the organization's objectives and needs have also increasingly become essential.

Following the introduction above, this study aims to conduct an empirical literature review concerning the relationship between IT governance and ERM and to create a checklist that organizations can use to see whether their IT governance and ERM align with their objectives and needs. This study should provide a better empirical understanding and insights regarding the interconnectedness and influence of IT governance and ERM on the organization's performance.

\section{LITERATURE REVIEW}

The concepts of IT governance and ERM have been used in many academic and professional works. To start with, IT governance generally revolves around its role in unifying the organization's IT and business process to enhance its strategic alignment (Levstek, Hovelja and Pucihar, 2018). It also includes the duty of the organization's board along with the procedures and conducts in managing, directing, and controlling the IT resources that aims to bring an added value to the organization and increase the likelihood to achieve its objectives. In this regard, the concept of IT governance is not the same as IT management. Broadbent (2003, cited in Levstek, Hovelja and Pucihar, 2018) pointed out that IT management concentrates on the creation and the implementation of specific decisions, whereas IT governance focuses on decision rights.

As for the ERM, the nature of the framework is to manage risks by using a holistic approach, and the purpose of its implementation is to improve and protect organization's value (Bromiley et al., 2015). The activities of ERM fundamentally consist of risks' identification, analysis, and evaluation, in which the findings from those activities are intended to enhance the organization's decision-making process, expand its awareness regarding the risks that reside within its business practice and environment, and ensure the risk-related information is uniformly distributed to all its management layers. Under this context, the role, commitment, engagement, and knowledge of the organization's board of directors and audit committee are imperative in ensuring its ERM programs are deployed and operate effectively (Fraser and Simkins, 2016). Furthermore, ERM does not solely focus on risks. It also has the function to identify the opportunities that the organization can exploit to further improve its competitiveness within the market, thus making them more resilient to the changes that occur within its environment and, at the same time, giving them the capability to maintain the level of its performance (Fiksel, 2015, pp. 19-34).

From a holistic perspective, IT governance and ERM can be considered as collaborative and complementary frameworks due to the similarities in their features. Both frameworks revolve around how organizations acquired and managed information to support their business activities and improve 
their decision-making process. In doing so, the organization must ensure all of its management layers understand its environment and the aspects within their business practice that require improvement. Thus, it can be concluded that the organization needs to make necessary changes, both in their IT- and risk-oriented aspects, to increase its likelihood of achieving its objectives and, ultimately, to create and obtain an added value to themselves.

\section{RESEARCH METHODOLOGY}

With respect to the aim of this study, the type of literature used in the comparative analysis focuses on quantitative research that utilize a statistical approach in investigating the relationship between IT governance and ERM. Moreover, the respective literatures are published in academic journals or international conference proceedings. This approach is selected to track the progress of empirical research regarding the role of IT governance and ERM and its influence on the organization's performance, and to uncover how the two frameworks supporting and complementing each other. Hence, any nonquantitative studies are excluded from the review and comparative analysis.

With regards to the year in which it acts as the baseline for the studies to be included in the empirical review, it is started from the year 2008. Accordingly, any empirical studies that are published before 2008 are excluded from the review. The respective year is selected due to it is the year where the International Organization for Standardization (ISO) and the International Electrotechnical Commission (IEC) issued the first edition of the ISO/IEC 38500:2008 standard entitled "corporate governance of information technology." It is also worth mentioning that ISO issued the first edition of the ISO 31000:2009 standard entitled "risk management - principles and guidelines" in 2009.

As for the steps in conducting the empirical review, this study uses the approach construed by Creswell (2011, cited in Aasi, Rusu and Han, 2014). The mentioned approach is consisting of five steps, namely by:

1. Establish the key terms applied in the study,

2. Find the appropriate studies with regards to the specified topic through the consultation of several types of information and database,

3. Critically evaluate and choose the study for review,

4. Organize the selected studies, and

5. Write a literature review those accounts for the summaries of the study.

Through the application of the literature review approach, the list of studies selected as the primary reference in uncovering the complementary and collaborative relationship between IT governance and ERM are presented in Table 1.

Table 1. Selected quantitative studies for empirical literature review

\begin{tabular}{cc}
\hline IT governance on ERM & ERM on IT governance \\
\hline Bradley and Pratt (2011) & Arnold et al. $(2011)$ \\
Nfuka and Rusu (2011) & Arnold et al. (2015) \\
Lunardi, Maçada and Becker (2014) & Saeidi et al. (2019) \\
Wilkin et al. (2016) & \\
Vincent and Pinsker (2020) & \\
\hline
\end{tabular}

\section{EMPIRICAL REVIEW FINDINGS AND DISCUSSION}

The summary of the key statistical findings concerning the influence of ERM on IT governance and vice versa are presented in Tables 2 and 3, respectively. The consensus of the selected studies revolves around the importance of strategic and process alignment on the organization's performance with regards to the implemented IT governance and ERM. Such consensus is derived and based on the significance of the organization's needs and objectives. 
Table 2. Influence of ERM on IT governance

\begin{tabular}{|c|c|c|}
\hline Authors & Data & Key statistical findings \\
\hline $\begin{array}{c}\text { AEA } \\
(2011)\end{array}$ & $\begin{array}{l}\text { CAE or in a similar position } \\
\text { from various industries } \\
\text { (113 respondents) }\end{array}$ & $\begin{array}{l}\text { 1. ERM is the antencendents of IT compatibility* } \\
\text { 2. IT compatibility provides organizational flexibility* } \\
\text { 3. The role of ERM, mediated by IT compatibility or not, } \\
\text { provides organizational flexibility* } \\
\text { 4. ERM provides positively affects the organization's } \\
\text { capability in managing its internal control* }\end{array}$ \\
\hline $\begin{array}{c}\text { AEA } \\
(2015)\end{array}$ & $\begin{array}{l}\text { CAE from various } \\
\text { industries } \\
\text { (155 respondents) }\end{array}$ & $\begin{array}{l}\text { 1. Higher strategic ERM effectiveness leads to higher IT } \\
\text { integration* } \\
\text { 2. The role of ERM, mediated by IT integration, } \\
\text { positively affects the organization's flexibility* } \\
\text { 3. The role of ERM, mediated by IT integration and } \\
\text { strategic flexibility, positively affects the } \\
\text { organization's supply chain performance* }\end{array}$ \\
\hline $\begin{array}{c}\text { SEA } \\
(2019)\end{array}$ & $\begin{array}{l}\text { Banks and Non-banking } \\
\text { financial intermediaries } \\
\text { (84 respondents) }\end{array}$ & $\begin{array}{l}\text { 1. ERM positively and significantly affect the } \\
\text { organization's competitive advantage* } \\
\text { 2. The aspect of ERM, IT strategy, IT structure, and } \\
\text { competitive advantage have a significant relationship } \\
\text { among them* } \\
\text { 3. The effect of ERM, mediated by IT strategy and IT } \\
\text { structure, significantly affects the organization's } \\
\text { competitive advantage* }\end{array}$ \\
\hline
\end{tabular}

Notes. $\mathrm{AEA}=$ Arnold et al.; $\mathrm{SEA}=$ Saeidi et al.; $\mathrm{CAE}=$ Chief Audit Executive. ${ }^{* * *}, * * *$ represents statistical significance at $1 \%, 5 \%$, and $10 \%$, respectively.

Following the findings with regards to the influence of ERM on IT governance presented in Table 2, the selected studies show that the role of ERM within an organization also focuses on ensuring its activities are align with its objectives and needs. The alignment between the organization's activities, needs, and objectives under ERM dictates its IT governance's function, purpose, and effectiveness level. The findings of Arnold et al. (2011) show that ERM positively affects the use of its IT, and it is statistically significant. The respective study explains that ERM practice within the organization's practice can enhance its ability to ensure the financial and managerial information are distributed effectively among its stakeholders, which improves its decision-making capabilities in detecting opportunities and threats within its surroundings. At the same time, it provides the organization a better control in managing its internal environment. This findings are supported and extended by the research of Arnold et al. (2015), which shows that the influence of ERM practices positively affects the IT integration of an organization, and it is statistically significant. Subsequently, the influence of ERM supported by IT also provides better organizational flexibility in obtaining competitive advantage and positively affects its supply chain performance. The finding that ERM positively influences the organization's competitive advantage is also confirmed by the research of Saeidi et al. (2019). In this context, the role of ERM, IT strategies, and IT structure positively affects the organization's competitive advantage and is statistically significant, which shows that the relationship between the three aspects is crucial to the organization's performance. Thus, the findings from the three studies concerning the influence of ERM on IT governance further emphasize the significance of strategic and process alignment.

Table 3.

Influence of IT governance on ERM implementation

\begin{tabular}{|c|c|c|}
\hline Authors & Data & Key statistical findings \\
\hline BP (2011) & CIO from healthcare industry & 1. IT governance positively influence IT risk \\
\hline
\end{tabular}




\begin{tabular}{|c|c|c|}
\hline Authors & Data & Key statistical findings \\
\hline & (165 respondents) & management* \\
\hline & & 2. Corporate entrepreneurship positively influences \\
\hline & & IT governance * \\
\hline & & 3. Corporate entrepreneurship positively influences \\
\hline & & IT risk management* \\
\hline $\begin{array}{c}\text { NR } \\
(2011)\end{array}$ & $\begin{array}{l}\text { Directors and managers of } \\
\text { public-sector organizations }\end{array}$ & $\begin{array}{l}\text { 1. The role of senior management is significant in } \\
\text { influencing the IT governance effectiveness* }\end{array}$ \\
\hline & (135 respondents) & $\begin{array}{l}\text { 2. The engagement with key stakeholders** and } \\
\text { IT/business communication and partnership }{ }^{* *} \text { has } \\
\text { a positive influence on IT governance }\end{array}$ \\
\hline & & $\begin{array}{l}\text { 3. The activities of IT strategies with organization's } \\
\text { strategies*, IT consolidation*, and IT leadership* } \\
\text { has a significant influence on IT governance }\end{array}$ \\
\hline & & $\begin{array}{l}\text { 4. The activities of policies and guidelines } \\
\text { consolidation and communication have a } \\
\text { significant positive effect on IT governance } \\
\text { performance** }\end{array}$ \\
\hline & & $\begin{array}{l}\text { 5. The awareness of IT governance and optimal IT } \\
\text { usage** along with the activities of attracting, } \\
\text { developing, and retaining IT professionals** has a } \\
\text { positive influence on IT governance }\end{array}$ \\
\hline $\begin{array}{c}\text { LMB } \\
(2014)\end{array}$ & $\begin{array}{l}\text { CIO of various industries } \\
\text { (87 respondents) }\end{array}$ & $\begin{array}{l}\text { 1. The factor of IT strategic alignment positively } \\
\text { influences IT governance effectiveness* }\end{array}$ \\
\hline & & $\begin{array}{l}\text { 2. The presence of IT governance structure, } \\
\text { processes, and relational mechanism has a positive } \\
\text { impact on the organization's IT alignment and } \\
\text { perceptions* }\end{array}$ \\
\hline & & $\begin{array}{l}\text { 3. The factor of IT value delivery positively influences } \\
\text { the IT governance effectiveness** }\end{array}$ \\
\hline & & $\begin{array}{l}\text { 4. The organization's IT risk management positively } \\
\text { influence its IT governance effectiveness* }\end{array}$ \\
\hline & & $\begin{array}{l}\text { 5. The activities of performance measurement } \\
\text { positively affect an organization's IT governance } \\
\text { effectiveness** }\end{array}$ \\
\hline $\begin{array}{c}\text { WEA } \\
(2016)\end{array}$ & $\begin{array}{l}\text { CIO and business executives } \\
\text { from various industries } \\
\text { (143 respondents) }\end{array}$ & $\begin{array}{l}\text { 1. Enhances organization's cost-saving capability due } \\
\text { to risk management under IT governance } \\
\text { policies*** }\end{array}$ \\
\hline & & 2. Clarity of accountability*** \\
\hline & & 3. Efficient resource allocation** \\
\hline VP (2020) & $\begin{array}{l}\text { IT executives from various } \\
\text { industries } \\
\text { (297 respondents) }\end{array}$ & $\begin{array}{l}\text { 1. The aspects of IT governance, communications-, } \\
\text { and monitoring-related IT practice positively and } \\
\text { significantly affects the organization's operations- } \\
\text { related IT practices** }\end{array}$ \\
\hline & & $\begin{array}{l}\text { 2. The aspect of ITG, mediated by the } \\
\text { communication-related IT practice, positively and } \\
\text { significantly affects the organization's operation- } \\
\text { related IT risk management practice* }\end{array}$ \\
\hline
\end{tabular}




\begin{tabular}{l}
\hline Authors $\quad$ Data \\
\hline Notes. $\mathrm{BP}=$ Bradley and Pratt; NR = Nfuka and Rusu; LMB = Lunardi, Maçada and Becker; WEA = Wilkin et \\
al.; $\mathrm{VP}=$ Vincent and Pinsker; $\mathrm{CIO}=$ Chief Information Officer. ${ }^{* * * * * * *}$ represents statistical significance at \\
$1 \%, 5 \%$, and $10 \%$, respectively.
\end{tabular}

As for the the statistical findings regarding the influence of IT governance on ERM presented in Table 3, it shows that the influence of IT governance is heavily concentrated in consolidating relevant information in enhancing the understanding of the organization's stakeholders concerning its needs and objectives. In which, the information generated from the applied IT governance framework aims to enhance the strategic decision-making capabilities of the organization under the risk-oriented perspective, especially to the risk that are associated to IT. For instance, following the research of Lunardi, Maçada and Becker (2014), it is found that the IT governance mechanism positively affects the IT risk management performance; although it is not statistically significant, the performance of IT risk management is statistically significant and positively affects the effectiveness of the organization's IT governance. The similar pattern also found in the results of Nfuka and Rusu (2011), who found that the activities of consolidating, communicating, and enforcing the policies and guidelines under the dimension of risk management and value delivery are statistically significantly and positively influence the effectiveness of IT governance. The findings of Bradley and Pratt (2011) show that IT governance positively influences the IT risk management performance of the organization, which is statistically significant under a direct relationship. Moreover, the study of Wilkin et al. (2016) shows that the influence of IT governance policies also permeates to the organization's ERM practice which increases its cost-saving capabilities and it is statistically significant. Lastly, the research of Vincent and Pinsker (2020) shows that IT governance positively affects the risk management practice by including IT-related monitoring and communication activities, and it is statistically significant. Moreover, it is also emphasized that the mentioned activities must be accompanied by adequate supervision and communication activities to ensure the organization's IT governance adequately supports its ERM activities.

To summarize the findings above, the IT governance mechanism that is applied within the organization does bring a positive effect on its ERM practice and, in turn, the performance of its ERM practice reciprocates the positive effect of IT governance by producing a higher-level quality of risk-oriented information in improving the organization's strategic decision-making capabilities. Hence, the findings of the selected studies affirm the benefits of using IT governance and ERM in supporting and improving an organization's performance mentioned in the conceptual research.

\section{IT GOVERNANCE AND ERM CHECKLIST: A PROPOSITION}

With respect to the findings of the empirical literature review discussed in the previous section, it shows that the organization's capability in aligning its ERM and IT governance frameworks dictates its performance level. Moreover, the function of the organization's structure, oversight, evaluation, and improvement are imperative in ensuring its IT governance and ERM mechanisms provide adequate support to keep its performance level and competitive advantages maintainable, financially and otherwise, in a highly dynamic environment. In this regard, Table 4 presents a checklist that organizations can use to assess the alignment of their applied IT governance and ERM frameworks concerning its needs and objectives.

Table 4.

IT governance and ERM implementation checklist

\begin{tabular}{llc}
\hline Component & \multicolumn{1}{c}{ Questions } & $\begin{array}{c}\text { Answer, Comments, } \\
\text { Considerations }\end{array}$ \\
\hline $\begin{array}{l}\text { Strategic } \\
\text { alignment }\end{array}$ & $\begin{array}{l}\text { 1. } \\
\text { Are the objectives of the organization } \\
\text { clearly defined and understood by the } \\
\text { executives? }\end{array}$ & $\square$ Yes $\square$ No \\
& 2. Are the needs of the organization clearly & $\square$ Yes $\mid \square$ No
\end{tabular}




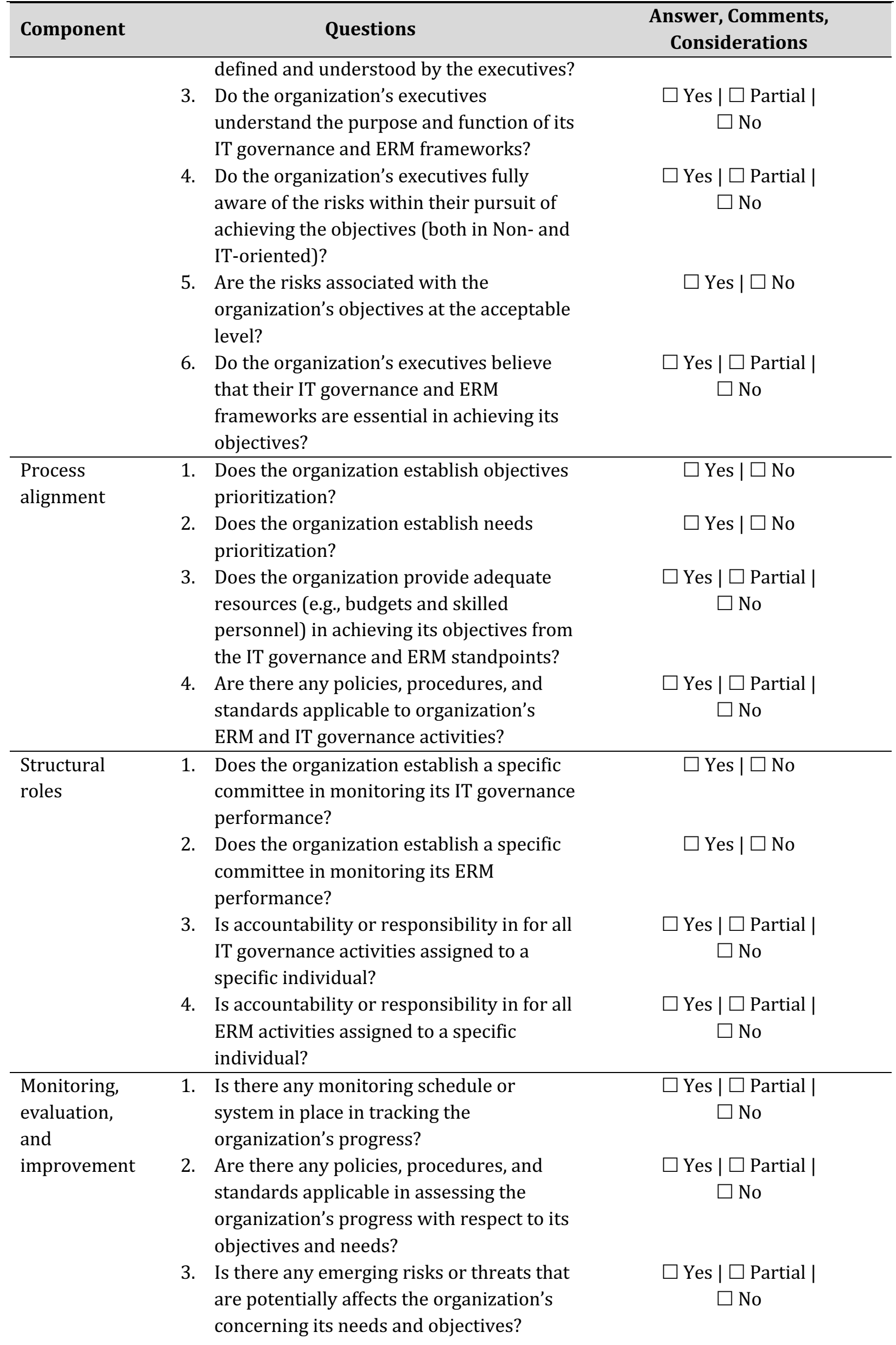




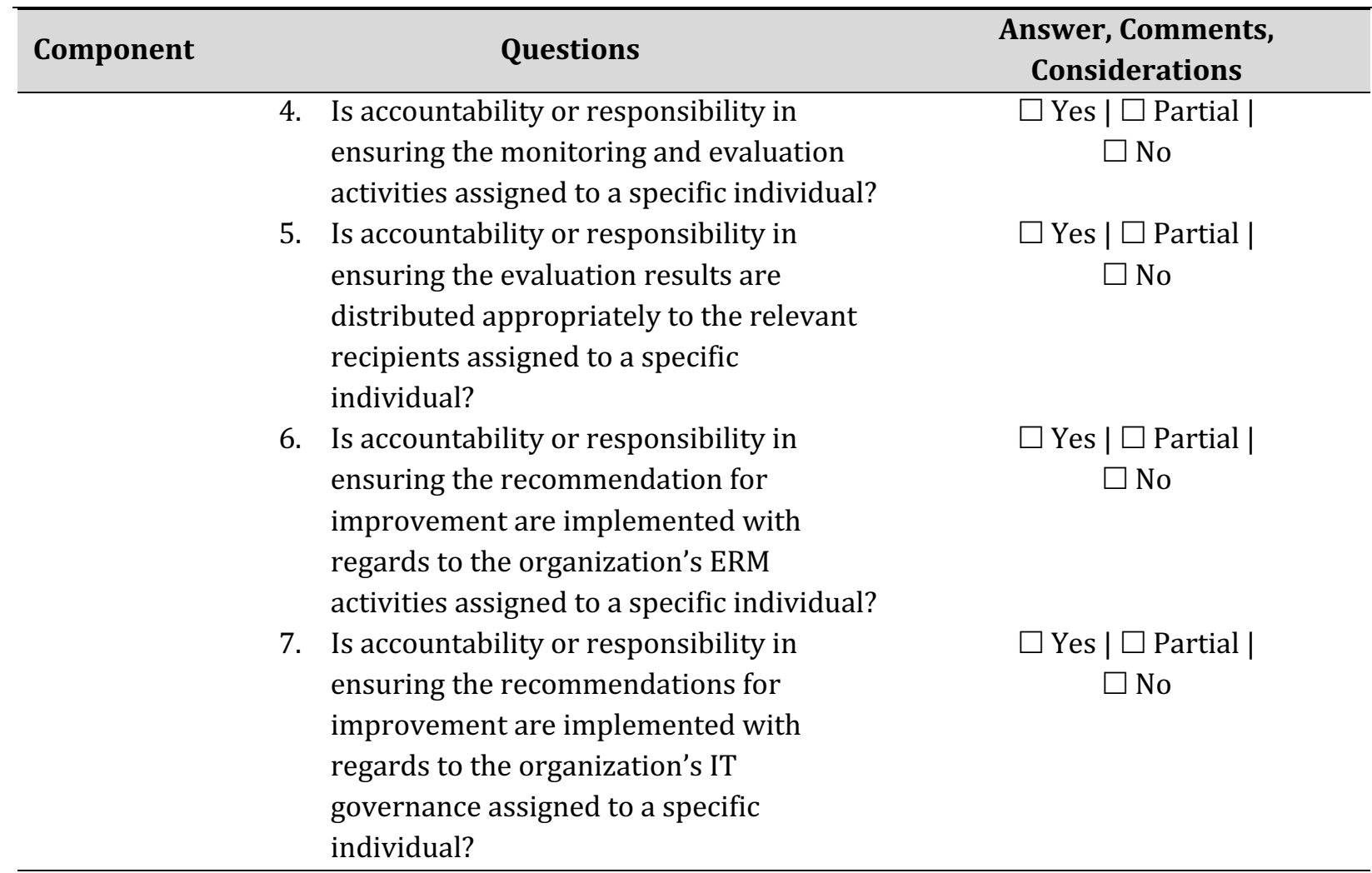

As presented in Table 4, the created checklist focuses on how well the organization understands its objectives and needs with respect to its IT governance and ERM practice. Therefore, the created checklist consists of indicative questions that can be treated as a guide to see the level of intensiveness of the organization in ensuring its IT governance and ERM frameworks support its pursuit in achieving its objectives and addressing its needs. At the same time, provide the information to assess the organization's effort in maintaining its competitive advantage.

\section{CONCLUSION}

The purpose of this study is to conduct an empirical literature review concerning the relationship between IT governance and ERM along with its influence on an organization's performance. Under this context, the empirical literature used in the review refers to the studies that use a statistical approach (i.e., quantitative approach) in investigating the relationship between IT governance and ERM. Additionally, a checklist concerning IT governance and ERM implementation is created based on the findings of the selected studies obtained from the empirical literature review.

Following the eight studies selected as the primary references in investigating the relationship between IT governance and ERM along with its influence on an organization's performance, the consensus among the studies' findings heavily concentrates on the significance and importance of strategic and process alignment. In general, the relationship between IT governance and ERM positively affects one another, and it is statistically significant. By which the organization's capability to align its IT governance and ERM dictates the organization's performance level and the effectiveness of the two implemented frameworks. In this regard, the proposed checklist can be used as a guide in assessing an organization's level of intensity and engagement in keeping its IT governance and ERM align with its objectives and needs, thus providing a quick overview of how the respective organization maintains its competitive advantage. The findings of the selected studies affirm the benefits that can be acquired by the organization as presented in conceptual research and, most of all, it can bring an added value to the organization, financially or otherwise.

Although this study can fulfill its aims, some limitations must be addressed. By design, this study does not 
conduct any empirical observation since it uses a literature review approach. Consequently, the level of insights provided by the findings is limited by nature. Therefore, it is advised for future research to conduct empirical research that is directly investigating the relationship between IT governance and ERM along with the degree of influence it brings to the organization. Furthermore, the created checklist is formulated under the findings and insights of the studies selected for the empirical literature review, and it has no prior testing. Thus, the effectiveness level of the respective checklist can be tested empirically in future research.

\section{REFERENCES}

Aasi, P., Rusu, L. and Han, S. (2014) 'The influence of culture on IT governance: A literature review', in 2014 47th Hawaii International Conference on System Sciences. Waikoloa: IEEE, pp. 4436-4445. doi: 10.1109/HICSS.2014.546.

Alijoyo, F. A., Bonita, I. and Sirait, K. B. (2021) 'The risk management maturity assessment: The case of Indonesian fintech firm', in Proceedings of The 4th International Conference on Research in Management and Economics. Milan: Diamond Scientific Publishing, pp. 13-24. doi: 10.33422/4th.imeconf.2021.05.21.

Arnold, V. et al. (2011) 'The role of strategic enterprise risk management and organizational flexibility in easing new regulatory compliance', International Journal of Accounting Information Systems, 12(3), pp. 171-188. doi: 10.1016/j.accinf.2011.02.002.

Arnold, V. et al. (2015) 'Leveraging integrated information systems to enhance strategic flexibility and performance: The enabling role of enterprise risk management', International Journal of Accounting Information Systems, 19, pp. 1-16. doi: 10.1016/j.accinf.2015.10.001.

Bouveret, A. (2018) Cyber risk for the financial sector: A framework for quantitative assessment. Working Paper WP/18/143. International Monetary Fund. Available at: https://www .imf.org/-/media/Files/Publications/WP/2018/wp18143.ashx.

Bowen, P. L., Cheung, M.-Y. D. and Rohde, F. H. (2007) 'Enhancing IT governance practices: A model and case study of an organization's efforts', International Journal of Accounting Information Systems, 8(3), pp. 191-221. doi: 10.1016/j.accinf.2007.07.002.

Bradley, R. V. and Pratt, R. M. E. (2011) 'Exploring the relationships among corporate entrepreneurship, IT governance, and risk management', in 2011 44th Hawaii International Conference on System Sciences. Kauai: IEEE, pp. 1-10. doi: 10.1109/HICSS.2011.203.

Bromiley, P. et al. (2015) 'Enterprise risk management: Review, critique, and research directions', Long Range Planning, 48(4), pp. 265-276. doi: 10.1016/j.lrp.2014.07.005.

Cisco (2020) Security outcomes study. Cybersecurity report series. Cisco. Available at: https:// www.cisco.com/c/dam/en/us/products/collateral/security/2020-outcomes-study-mainreport.pdf.

Farrell, M. and Gallagher, R. (2015) 'The valuation implications of enterprise risk management maturity', Journal of Risk and Insurance, 82(3), pp. 625-657. doi: 10.1111/jori.12035.

Fiksel, J. (2015) Resilient by design: Creating businesses that adapt and flourish in a changing world. 1st edn. Washington DC: Island Press. doi: 10.5822/978-1-61091-588-5.

Fraser, J. R. S. and Simkins, B. J. (2016) 'The challenges of and solutions for implementing enterprise risk management', Business Horizons, 59(6), pp. 689-698. doi: 10.1016/j.bushor.2016 .06.007.

Levstek, A., Hovelja, T. and Pucihar, A. (2018) 'IT governance mechanisms and contingency factors: Towards an adaptive IT governance model', Organizacija, 51(4), pp. 286-310. doi: 10.2478/orga2018-0024.

Lunardi, G. L., Maçada, A. C. G. and Becker, J. L. (2014) 'IT governance effectiveness and its antecedents: An empirical examination in Brazilian firms', in 2014 47th Hawaii International Conference on System Sciences. Waikoloa: IEEE, pp. 4376-4385. doi: 10.1109/HICSS.2014.540.

Nfuka, E. N. and Rusu, L. (2011) 'The effect of critical success factors on IT governance performance', Industrial Management \& Data Systems, 111(9), pp. 1418-1448. doi: 10.1108 
/02635571111182773.

Nocco, B. W. and Stulz, R. M. (2006) 'Enterprise risk management: Theory and practice', Journal of Applied Corporate Finance, 18(4), pp. 8-20. doi: 10.1111/j.1745-6622.2006.00106.x.

Nolan, R. and McFarlan, F. W. (2005) 'Information technology and the board of directors', Harvard Business Review, 83(10), pp. 96-106. Available at: https://hbr.org/2005/10/information-technology-andthe-board-of-directors.

Rubino, M. and Vitolla, F. (2014) 'Corporate governance and the information system: How a framework for IT governance supports ERM', Corporate Governance, 14(3), pp. 320-338. doi: 10.1108/CG06-2013-0067.

Saeidi, P. et al. (2019) 'The impact of enterprise risk management on competitive advantage by moderating role of information technology', Computer Standards \& Interfaces, 63, pp. 67-82. doi: 10.1016/j.csi.2018.11.009.

Trautman, L. J. and Altenbaumer-Price, K. (2011) 'The board's responsibility for information technology governance', John Marshall Journal of Computer \& Information Law, 28(3), pp. 313-342. Available at: http://repository.jmls.edu/jitpl/vol28/iss3/1.

Turel, 0. and Bart, C. (2014) 'Board-level IT governance and organizational performance', European Journal of Information Systems, 23(2), pp. 223-239. doi: 10.1057/ejis.2012.61.

Vincent, N. E. and Pinsker, R. (2020) 'IT risk management: interrelationships based on strategy implementation', International Journal of Accounting \& Information Management, 28(3), pp. 553575. doi: 10.1108/IJAIM-08-2019-0093.

Wilkin, C. L. et al. (2016) 'Exploring differences between smaller and large organizations' corporate governance of information technology', International Journal of Accounting Information Systems, 22, pp. 6-25. doi: 10.1016/j.accinf.2016.07.002.

Wilkin, C. L. and Chenhall, R. H. (2010) 'A review of IT governance: A taxonomy to inform accounting information systems', Journal of Information Systems, 24(2), pp. 107-146. doi: 10 .2308/jis.2010.24.2.107. 